University of Wollongong

Research Online

Faculty of Law, Humanities and the Arts Papers (Archive)

Faculty of Arts, Social Sciences \& Humanities

$1-1-2017$

When Commerce, Science and Leisure Collaborated: the NineteenthCentury Global Trade Boom in Natural History Collections

Anne Coote

University of New England

Alison M. Haynes

University of Wollongong, amh304@uowmail.edu.au

Jude Philp

University of Sydney

Simon Ville

University of Wollongong, sville@uow.edu.au

Follow this and additional works at: https://ro.uow.edu.au/lhapapers

Part of the Arts and Humanities Commons, and the Law Commons

Research Online is the open access institutional repository for the University of Wollongong. For further information contact the UOW Library: research-pubs@uow.edu.au 


\title{
When Commerce, Science and Leisure Collaborated: the Nineteenth-Century Global Trade Boom in Natural History Collections
}

\author{
Abstract \\ Natural history products formed an important, but little studied, component of the globalization of trade in \\ the mid nineteenth century. The trade, specifically in zoology, occurred in the face of considerable \\ challenges. It penetrated some of the more remote areas of the globe; its products were heterogeneous \\ and difficult to price; and exchange occurred among scientists, commercial traders, and collectors, each \\ of whom had their own particular practices and mores. This article charts the dimensions of this trade \\ and offers explanations about the ways in which its complexities were addressed through major \\ developments in taxidermy, taxonomy, transport and business logistics, alternative forms of exchange, \\ and trust-based networks. More broadly, our work speaks to current developments in global history, \\ imperial networks, and the history of scientific collecting.

\section{Disciplines} \\ Arts and Humanities | Law

\section{Publication Details} \\ Coote, A., Haynes, A., Philp, J. \& Ville, S. (2017). When Commerce, Science and Leisure Collaborated: the \\ Nineteenth-Century Global Trade Boom in Natural History Collections. Journal of Global History, 12 (3), \\ 319-339.
}




\section{When Commerce, Science and Leisure Collaborated: the Nineteenth-Century Global Trade Boom in Natural History Collections}

Anne Coote, ${ }^{1}$ Alison Haynes, ${ }^{2}$ Jude Philp, ${ }^{3}$ and Simon Ville ${ }^{4}$

${ }^{1}$ School of Humanities, University of New England, Armidale, NSW 2351, Australia E-mail: acoote4@une.edu.au

2 PhD candidate in Biology, Faculty of Science, Medicine and Health University of Wollongong, Wollongong NSW 2522, Australia

E-mail: alison.haynes@internode.on.net

${ }^{3}$ Macleay Museum, University of Sydney, Camperdown NSW 2006 Australia

E-mail: jude.philp@sydney.edu.au

${ }^{4}$ School of Humanities and Social Inquiry, Faculty of Law, Humanities and the Arts, University of Wollongong, Wollongong NSW 2522, Australia

E-mail: sville@uow.edu.au ${ }^{1}$

\section{Abstract}

Natural history products formed an important, but little studied, component of the globalisation of trade in the mid nineteenth century. The trade, specifically in zoology, occurred in the face of considerable challenges. It penetrated some of the more remote areas of the globe; its products were heterogeneous and difficult to price; and exchange occurred among scientists, commercial traders, and collectors, each of whom had their own particular practices and mores. This article charts the dimensions of this trade and offers explanations about the ways in which its complexities were addressed through major developments in taxidermy, taxonomy, transport and business logistics,

\footnotetext{
${ }^{1}$ Corresponding author
} 
alternative forms of exchange, and trust-based networks. More broadly, our work speaks to current developments in global history, imperial networks, and the history of scientific collecting.

Keywords:. Exchange; networks; taxidermy; technology; zoology trade

\section{Introduction}

An international trade of remarkable proportions grew to prominence in the nineteenth century. While the collecting and trading of natural history goods already had a long history in Europe, new and distinctive elements emerged in the nineteenth century. Zoology in many forms became the principal focus of a new collecting boom as curiosity about unfamiliar animals from distant lands was increasingly stimulated by publications and through news from settlers, traders and travellers. Collecting examples of new species became a popular pastime as many individuals emulated the elite collectors of earlier centuries. Public organisations, particularly museums and universities, grew in number and broadened their educational and professional research activities in the field of natural history. Entrepreneurs saw new opportunities for profitable commerce arising from a larger market that could no longer be negotiated primarily through the personal connections and scholarly communications of early modern times.

However, the expansion of the trade in response to new and growing sources of demand faced many challenges. If the distinguishing characteristics of a species were poorly understood this created difficulties agreeing on a sale price. Capture and preservation 
were far more significant problems in zoology than for other products of the natural world because they could more easily deteriorate or be damaged on long journeys. The two problems hampered each other in developing the trade: heterogeneity of quality on top of uncertainty of its species type. A third source of uncertainty was the fact that buyers and sellers, who were variously scientists, traders, and collectors, came from social groups unaccustomed to interaction. While unfamiliarity and lack of trust were mitigated by the relatively small network of elite collectors in earlier times, by the nineteenth century the growth of large scale popular collecting threatened to overwhelm these personal channels.

The article examines these challenges and explains how they were largely overcome. In summary, the coming together of science, business and personal collecting, while initially a source of uncertainty, also provided most of the solutions. Important advances in science, collecting and commerce provided mutual benefits. Clearer scientific classification of species enabled more nuanced collecting, accurate pricing and a better understanding of relative values for exchange and long term collection. Improvements in preservation techniques, as well as taxidermy methods, assisted business logistics, scientific research, and long term collecting. Technological advances in transportation and communications enabled scientists and collectors to purchase in a much more extensive market. During the nineteenth century the modernisation of business in scale and practices ensured that emerging organisations could efficiently handle complex long distance trading. Marketing and branding allowed for a greater reach to potential clientele, including scientists and popular collectors who were dependent on the same type of information sources. Specific expeditions of scientists, collectors and commercial agents provided reach into remoter areas. The interaction of 
scientific knowledge, the technologies of transport and preservation, and the modernisation of commercial practices thus lies at the heart of the article and our exploration of the nature of this trade.

\section{The parameters of the natural history trade}

Collecting natural history specimens for medicinal purposes or for simple curiosity has a long international history; for example, Roman legionnaires returned home with specimens of seashells as keepsakes of their experiences of foreign places. It seems likely, though, that long distance trade or exchange in these products, or in the useful knowledge associated with them, was relatively small until the early modern period. By then, interest in natural history had become part of the republic of letters movement, which involved the international exchange of scientific ideas facilitated through honorific gifts. Correspondence, in tandem with the introduction of illustrated encyclopaedias and informative repertories, enabled this exchange of ideas and aroused interest in collecting natural history specimens. Although some commercial exchanges took place in the early modern period, this did not overcome the underlying distrust between the code of reciprocity in the learned world and the code of profit in the commercial world. ${ }^{2}$ Before the nineteenth century the logistical challenges of acquisition and preservation had largely confined successful trade to botanical and mineralogical items, together with insects and, with limited success, some smaller

\footnotetext{
2 Daniel Margoscy, Commercial visions. Science, trade and visual culture in the Dutch Golden Age, Chicago: University of Chicago Press, 2014, pp. 29-37. Tomomi Kinukawa, 'Learned versus commercial? The commodification of nature in early modern natural history specimen exchanges in England, Germany and the Netherlands', Historical Studies in the Natural Sciences, 43, 5, 2013, pp. 589-618. Also see Raymond L. Lee, 'American cochineal in European commerce, 1526-1625', Journal of Modern History, 23, 3, 1951, pp. 205-24.
} 
animals. ${ }^{3}$ Collecting in botany was a foundation of commercially-led research as governments and their chartered trading companies vied with each other for dyes, foodstuffs and medicinal plants. The development of botanic gardens and herbaria in Europe from the sixteenth century demonstrates the relative age of this trade in comparison with zoology. ${ }^{4}$ But these products tended not to enrich the new museums of the nineteenth century, since plants already had their place in botanical gardens and herbaria.

The spreading geographic reach of overseas trade, exploration, and colonisation in the eighteenth century opened European eyes more widely to an apparently endless natural world of previously unknown zoological species, indicative of much greater biological diversity than hitherto appreciated. Highly descriptive, sometimes illustrated, publications of zoology reinforced this revelation. They included Maria Sibylla Merian's Metamorphosis insectorum Surinamensium, the product of her own field work in Suriname and published in 1705, Louis Renard's colourful work on fish, crayfish and crabs (1718-19), and Georges-Louis Leclerc, Comte de Buffon's Histoire Naturelle, 36 volumes of which were published between 1749 and 1789.5 Trade was also stimulated by travelogues and memoirs which, like Benjamin Barton's Fragments of the natural

\footnotetext{
${ }^{3}$ Clare Flemming and Jason D. Weintraub, 'Notes on 18th century Lepidoptera specimens in the Archives of the Academy of Natural Sciences', Proceedings of the Academy of Natural Sciences of Philadelphia, 162, 1, 2013, pp. 187-193.

${ }^{4}$ William T. Stearn, 'Sources of information about botanic gardens and herbaria', Biological Journal of the Linnean Society, 3, 3, 1971, pp. 225-233; José Ramón Marcaida and Juan Pimantel, 'Dead natures or still lifes? Science, art, and collecting in the Spanish Baroque' in Daniela Bleichmar and Peter C. Mancall eds. Collecting across cultures. Material exchanges in the early modern Atlantic world, Philadelphia: University of Pennsylvania Press, 2011, p. 111.

${ }^{5}$ Maria Sibylla Merian, Metamorphosis insectorum Surinamensium, Amsterdam: Voor den auteur, 1705; Paula Aschrynemakers, 'Made Merian', in Tom Baione, ed., Natural histories: Extraordinary rare book selections from the American Museum of Natural History, New York: Sterling Signature, 2014, pp. 24-27; Louis Renard, Poissons, ecrevisses et crabes, de diverses couleurs et figures extraordinaires, que l'on trouve autour des isles Moluques et sur les côtes des terres Australes, Amsterdam: Chez Reinier and Josué Ottens, 1754; Benjamin Barton, Fragments of the natural history of Pennsylvania, Philadelphia: Way and Groff, 1799; Londa Schiebinger, Nature's body: Sexual politics and the making of modern science, London: Pandora, 1993, pp. 203-4.
} 
history of Pennsylvania (1799), could be a mixture of purposeful observations and what Barton (quoting Donne) called 'fragmentary rubbish'. The development of methods of classification including Carl von Linné’s Systema Naturae (1735 and 1758) offered ways of cataloguing the multiplicity of natural wonders such books revealed. ${ }^{6}$ At the same time, changing attitudes, inspired by the Enlightenment, forged a belief that the natural world was for the benefit of, and exploitation by, humans.

By the nineteenth century, these underlying factors had made the observation, collection, and scientific study of zoology both respectable and highly fashionable. The growing interest of private collectors and museum scientists drove increased demand for natural history specimens. Several major private collections had been built in the eighteenth century, including those of Carl von Linné (purchased via Joseph Banks by John Smith in 1783), Hans Sloane, whose 71000 objects formed the basis of the British Museum's establishment in 1753, and the Duchess of Portland. The latter's collection was so large that after her death it took thirty-eight days to sell at auction. ${ }^{7}$ 'Cabinets of curiosities' had become emblems of social and cultural status for the wealthy for many decades, but by the nineteenth century the practice of collecting had extended to the industrial middle classes, facilitated by their growing wealth and leisure. 'Mounts', taxidermied animal skins preserved in a life-like position, became a fashionable form of decor in the Victorian home. Some were purchased ready-made from dealers, but others were created in the home, where taxidermy was practised by many middle-class

\footnotetext{
${ }^{6}$ Carl von Linné, Systema naturae, Lugduni Batavorum: Apud Theodorum Haak, 1735; Carl von Linné Systema naturae, Lipsiae: W. Engelmann, $10^{\text {th }}$ ed., 1758.

${ }^{7}$ Schiebinger, Nature's body, p. 202.
} 
Victorian women, as an extension of the decorative arts of sewing, embroidery and painting, which were considered suitably genteel female pastimes. ${ }^{8}$

In a democratising age, aspirational, low status individuals emulated their social and economic 'superiors' by collecting natural history specimens, albeit on a more modest scale. From the 1830s, popular natural history field clubs began to flourish in the United Kingdom, with activities that included excursions, discussion groups, recording of their transactions, and the acquisition of relevant publications. ${ }^{9}$ Similar societies or clubs were established in the United States after the Civil War, and in Canada the Ottawa Field Naturalists Club was founded in 1863. By the mid nineteenth century, the number of 'collections' of one sort or another in Europe was estimated to be in the region of $100,000.10$

Reflecting this growing interest and activity, the number of publications dealing with zoology increased dramatically. These included the works of travelling naturalists, such as François Péron, Charles Darwin and Mary Kingsley. Journals produced by learned societies, such as the Zoological Society of London, kept their members informed about the discovery of new species, while popular science periodicals had the capacity to reach many more readers. ${ }^{11}$ Pitched to a socially diverse set of consumers of both genders and a range of ages, these publications facilitated more informed popular

\footnotetext{
8 Thad Logan, The Victorian parlour: a cultural study, New York: Cambridge University Press, 2001; Cynthia Bornhorst-Winslow, "The Important Role Played by Household Crafts in the Lives of NineteenthCentury Women in Britain and America', Masters Thesis, Wright State University, Dayton, Ohio, 2012, pp. 4, 34-35, 42; Vera Norwood, Made from this earth: American Women and Nature, Chapel Hill, NC: University of North Carolina Press, 1993.

${ }^{9}$ David E. Allen, The naturalist in Britain: a social history, Princeton, NJ: Princeton University Press, 1976. ${ }^{10}$ William Swainson, Taxidermy with the biography of zoologists, London: Longman, Orme, Brown, Green, and Longman, 1840.

${ }^{11}$ Geoffrey Cantor, Sally Shuttleworth and Jonathon R. Topham, 'Representations of science in the nineteenth century periodical press', Interdisciplinary Science Reviews, 28, 3, 2003, p. 161; Susan SheetsPyenson, 'Low scientific culture in London and Paris, 1820-1875', quoted in Ruth Barton, 'Just before Nature: The purposes of science and the purposes of popularization in some English science journals in the 1860s', Annals of Science, 55, 1, 1998, p. 2.
} 
collecting focused on new species, in contrast to the opportunistic acquisitions of the undiscerning eighteenth-century sailor, wont to collect almost any unfamiliar item. Whereas once people could merely wonder at the illustrations and descriptions of new species, the scientific, technological and organisational advances of the natural history trade in the nineteenth century gradually made ownership of physical artefacts a reality for collectors. ${ }^{12}$

While natural history museums had been established in the early modern period, a substantial expansion took place in their role and numbers in the nineteenth century. Accompanying a much broader interest in collecting, museums shed their elite, often royal, nature to become public spaces for people to enjoy and learn from viewing the specimens on display..$^{13}$ By the 1850 s, many of the major European cities, including Berlin, Vienna and Naples, had their own specialist natural history museums. Public interest in the field in the US can be gauged by the establishment of the publicly-funded natural history museum, Harvard's Museum of Comparative Zoology (1860). By 1900, Great Britain and the United States each boasted about 250 natural history museums, while France had 300, and Germany $150 .{ }^{14}$ Colonies established their own museums both to give their settlement visibility and to collaborate in supporting the development of national collections of the European powers. ${ }^{15}$ Musée de Nouvelle Calédonie was established to create collections for the International Paris exhibition. ${ }^{16}$ Museums in

\footnotetext{
${ }^{12}$ Kathleen S. Murphy, 'Collecting slave traders: James Petiver, natural history, and the British slave trade', William and Mary Quarterly, 70, 4, 2013, p. 669.

${ }^{13}$ John M. Mackenzie, Museums and Empire: natural history, human cultures, and colonial identities, Manchester: Manchester University Press, 2009, p. 2.

${ }^{14}$ Susan Sheets-Pyenson, Cathedrals of science: the development of colonial natural history museums during the late nineteenth century, Montreal: McGill-Queen's University Press, 1988.

${ }^{15}$ For example in colonial India, Shaila Bhatti, Translating museums: a counterhistory of South Asian museology, Walnut Creek CA: Left Coast Press, 2012, p. 52

${ }^{16}$ Jude Philp, 'Headly takes a holiday' in Sarah Byrne, Anne Clarke, Rodney Harrison, and Robin Torrence, eds., Unpacking the collection: networks of material and social agency in the museum, New York: Springer, 2011, p. 274.
} 
Calcutta (1814), Port Louis (1842), and Batavia (1862) were important 'field stations' for the variously connected empires.

In addition to their growing public role, the curators of these museums were responsible for advancing scientific research. By the mid nineteenth century, museumsponsored collecting began to take a more rigorous, methodical and scientific character, further contributing to the growth of international trade in order to fill collection gaps with items that were rare in some regions but common in others. Collections, appropriately realised, could be used to further science, by enhancing understanding of taxonomy and biodiversity and providing important knowledge about a species such as its normal geographic range. American zoological collection progressed from the eighteenth century's descriptive catalogue towards systematic zoology under the influence of Louis Agassiz, whose 1848 publication Principles of Zoology almost immediately became the standard text. ${ }^{17}$

It was the huge increase in public and private collecting, therefore, that led to the growth of an extensive international commercial trade in zoological products. This was manifested in a vast geographical web of sales and exchanges, which involved field collectors, freight forwarders, natural history retailers, private collectors and museum personnel, and was supplemented by auctions, exhibitions and expeditions. This complex trade developed during what is generally considered the first era of globalisation in the second half of the nineteenth century. ${ }^{18}$ The zoology trade benefited

\footnotetext{
17 Wesley R. Coe, 'A century of zoology in America', in Edward Salisbury et al, A century of science in America, New Haven: Yale University Press, 1928, p. 366.

${ }^{18}$ Kevin. H. O'Rourke and Jeffrey G. Williamson, Globalization and history: The evolution of a nineteenthcentury Atlantic economy, Cambridge, MA: MIT Press, 1999; Michael D. Bordo, Alan M. Taylor, and Jeffrey G. Williamson, eds., Globalization in historical perspective, Chicago: University of Chicago Press, 2003; Jürgen Osterhammel and Niels P. Peterson, Globalization: A short history, Princeton, NJ: Princeton University Press, 2005.
} 
from the globalising logistics of international trade - shipping lines, finance, and cargo handling - and in a number of respects can be regarded as a global trade. Zoology specimens from remote locations across many continents were supplied to consumers in the developed world, particularly North America and Western Europe. In 1839 French conchologist, Jean de Grateloup, remarked that from the port of Bordeaux alone he could acquaint himself with rare and interesting specimens from Oceania, the East Indies and the Americas. ${ }^{19}$ The $13^{\text {th }}$ Earl of Derby, a major collector, maintained a remarkable network of professional collectors supplying him from many corners of the globe, including the 'New World', the Far East, Africa and Australasia. ${ }^{20}$ In order to connect the many remote capture locations to the major cities of Europe and North America, shipping passed through trading centres in Asia, South Africa, Australasia, and the Pacific. ${ }^{21}$

The stamp of empire is clear along many of these trade routes, museum linkages and collecting networks, particularly because of the use of well-established long distance commercial and shipping connections. Nevertheless, the European metropoles sometimes ceded control to their trans-colonial connections and local procurement agents. ${ }^{22}$ For example, within the British Empire, in 1901, 'specimens of natural history' were exported from Australia to Hong Kong, the United Kingdom and British Columbia,

\footnotetext{
${ }^{19}$ Jean P.S. de Grateloup, Actes de la société Linnéenne de Bordeaux, 11, 1839, p. 161.

${ }^{20}$ Clemency Fisher and Christine E. Jackson, 'The 13th Earl of Derby as a scientist', in Clemency Fisher, ed., A passion for natural history: The life and legacy of the $13^{\text {th }}$ Earl of Derby, Liverpool: Board of Trustees of the National Museums and Galleries Merseyside, 2002, pp. 47-9.

${ }^{21}$ Francis E. Hyde, Far Eastern Trade, 1860-1914, London: A \& C Black, 1973.

${ }^{22}$ See Alan Lester, Imperial networks: Creating identities in nineteenth-century South Africa and Britain, London: Routledge, 2001; Dipesh Chakrabarty, Provincializing Europe, Princeton: Princeton University Press, 2000; Helen Cowie, Conquering nature in Spain and its empire, 1750-1850, Manchester: Manchester University Press, 2011 provides a more traditional perspective of trade along Empire lines.
} 
while similar imports came from Fiji, British New Guinea, USA, and South Africa. ${ }^{23}$ Major collectors and dealers also sometimes worked across imperial powers in the trade: in 1836-40 the Earl of Derby travelled to the Philippines with letters from Madrid guaranteeing his assistance and protection. ${ }^{24}$

Alongside natural history collecting, the market for animal skins and feathers for fashion and decoration also grew. The passion for decorative animal parts would see both its greatest extravagances and its demise towards the end of the century with the rise of protectionist societies. ${ }^{25}$ In addition, as Helen Cowie has demonstrated, a trade in live animals developed in the nineteenth century, particularly to serve the growing popularity of public zoos. ${ }^{26}$ While not the central focus of this article, there is naturally commercial overlap between these different uses. Dealers like Adolphe Boucard were closely entwined in the zoology trade, but some of his trade birdskins would have been repurposed for millinery.

$<<$ figure 1 here >>

Figure 1 provides a visual, if stylised, depiction of the complex commercial supply chain of the trade in zoology specimens. There was no single pathway from sourcing to final consumer. Field collection involved a diverse set of actors and activities from indigenous populations, part-time hunters, missionaries, members of the army and

\footnotetext{
23 State Government of Queensland, Statistics of the State of Queensland 1901, Brisbane: Government Printer, 1902, pp. 176, 229; Annual Reports of British New Guinea (1889-98), Brisbane: Government Printer.

${ }^{24}$ Fisher and Jackson, '13 th Earl of Derby', p. 76.

25 Greg Murrie, 'Death in life: Curare, restrictionism and abolitionism in Victorian and Edwardian antivivisectionist thought', in Jay Johnson and Fiona Probyn-Rapsey eds., Animal Death, Sydney: Sydney University Press, 2007, pp. 240-252.

${ }^{26}$ Helen Cowie, Exhibiting animals in Nineteenth-century Britain: empathy, education. entertainment, Basingstoke, Hamp.: Palgrave, Macmillan, 2014.
} 
navy, locals, through to individual salaried and commercial collectors. ${ }^{27}$ Some of this trade went directly to the end user, such as a private collector-owner or the cabinets and research areas of museums. Museums might also act as intermediaries by on-selling or exchanging products with other museums looking to fill collection gaps. However, as the magnitude of the trade expanded beyond the grasp of many personal networks, the supply chain increasingly included a range of commercial intermediaries - consignors, wholesale traders, retailers, taxidermists and the like. Some were non-specialists who combined natural history with other business opportunities; in at least one case, taxidermy with hairdressing! ${ }^{28}$ Others, though, were vertically integrated, that is combining sequential stages of activity such as collecting and taxidermy with wholesale and retail trading. Several operators were multinational enterprises of remarkable resource and reach. The Hamburg-based Godeffroy Company controlled its trade by funding collectors like Otto Finsch (colonial officer for Kaiser Willhelm Land in New Guinea) who combined a knowledge of science with an understanding of the colonial context. This facilitated consistency in product quality and the provision of product knowledge from provenance to final sale. In the great majority of cases where transactions along the supply chain were not internalised within a single organisation, a broad range of exchange methods occurred from private sales to auctions, barter, exhibitions and gifts. The manner in which these different types of transactions were completed among buyers and sellers, often unknown to each other, across business, science and collecting is one of the remarkable achievements of the trade.

\footnotetext{
${ }^{27}$ Bettins Dietz, 'Making natural history: Doing the Enlightenment', Central European History, 43, 1, 2010, p. 29; Jivanayakam C. Daniel and Baljit Singh, Natural history and the Indian army, Bombay: Oxford University Press, 2009.

${ }^{28}$ Sarah Amato, Beastly possessions: animals in Victorian consumer culture, Toronto: University of Toronto Press, 2015, p. 191.
} 
In Europe and North America, natural history dealers and retailers sprang up on streets across many major cities to serve collectors. By 1895 there were 52 in Berlin alone, and a further 33 in Vienna, 26 in London, and 17 in Paris. ${ }^{29}$ In the USA there were more than 100 natural history dealers at the end of the nineteenth century. ${ }^{30}$ The network of dealers was also geographically very dense in some countries - there appears to have been at least one small trader in most major towns in the United Kingdom. ${ }^{31}$ While many of these businesses were localised in nature, there were several that had substantial establishments trading with many countries. The largest American dealer was Ward's Natural History Establishment, of Rochester, New York, which boasted individual collectors, museums and educational institutions as clients. Its founder, Henry Augustus Ward, had established a large international 'collectors' network. ${ }^{32}$ Ward's had sold more than US\$730,000 worth of various natural history specimens to 100 American museums by the end of the nineteenth century. At the collecting end of the trade, in 1901 the British Museum received into its bird collection alone 19,358 items obtained from many individuals and firms from far and wide across the globe. ${ }^{33}$ Another indication of the growth of the trade and the broad collector population was the participation by specimen dealers in major international trade exhibitions that emerged in the second half of the nineteenth century. The Crystal Palace Exhibition in London in 1851 'seemed to offer an extraordinary insight into the possibility of

\footnotetext{
${ }^{29}$ Henri Reiling and Tat'jána Spunarová, 'Vaclav Fric (1839-1916) and his influence on collecting natural history', Journal of the History of Collections, 17, 1, 2005, pp. 23-43.

${ }^{30}$ Mark Barrow, 'The specimen dealer: entrepreneurial natural history in America's Gilded Age', Journal of the History of Biology, 33, 3, 2000, pp. 493-534.

${ }^{31}$ Curators' correspondence to taxidermists across Britain in 'Vertebrata', 1898, letter book DF200 230, archives of the Natural History Museum, London.

32 Barrow, 'The specimen dealer', pp. 502-10.

33 Anon., The history of the collections contained in the natural history, vol. II, London: Trustees of the British Museum, 1904, p. 286.
} 
scientific globalization'.34 It provided the blueprint for many subsequent exhibitions such as the Exposição Internacional do Porto, 1865, Dublin International, 1865, the Colonial and Indian Exhibition of 1886 in London, and the Chicago Exposition, 1886. As well as facilitating commercial transactions, the exhibitions further stimulated the growth of museums by offering the opportunities to purchase significant collections.

From the last years of the nineteenth century, attitudes to nature and motivations for collecting began to change. While these were uncertain economic times and many of the major geographic explorations and discoveries had passed their peak years, it was the changing attitude towards the natural world, born of new perspectives in both science and philosophy, that shifted preferences and behaviours. Greater appreciation of the living natural world, including its observation and study, gradually predominated and gained momentum through activist organisations such as the Audubon Society and from the romanticism of the arts and crafts movements. Maturing photographic technology also played a role; as Griffiths has noted, the gun was no longer the only intermediary with nature, which 'could be captured with camera and field glass instead of with gun and trap'.35 In May 1915 the Times Literary Supplement was drawn to conclude, 'the time has come when the hunter must give way to the observer'.

Zoological study was extending beyond classification to embrace other disciplines, including an ecological focus, an approach Martha Maxwell had pioneered in Colorado as early as the 1870 s. $^{36}$ Novel specimens were no longer the principal objective of fieldwork; what was now sought was information on how animals lived and inter-

\footnotetext{
34 MacKenzie, Museums and Empire, p. 2.

35 Tom Griffiths, Hunters and collectors: The antiquarian imagination in Australia, Melbourne: Cambridge University Press, 1996, pp. 130-2.

${ }^{36}$ Elizabeth Oakes, 'Martha Dartt Maxwell', in Encyclopedia of World Scientists, New York: Facts on File, 2007, pp. 494-5.
} 
related. The scientific interest was reflected in public exhibits that came to dominate museums of the twentieth century. By the end of the nineteenth century, both the British taxidermist Rowland Ward and the American Carl Akeley were experimenting with taxidermy methods that used life-study and sculptural techniques to emphasise musculature and expression in a given animal. Here a skin was stretched over a cast created for both the interior structure and features such as teeth. These 'life-like' taxidermied specimens were often intended for museum dioramas that specifically emulated the specimens' habitat, interrelations with other species and movements for public edification.

\section{The challenges of the trade}

The previous section describes a trade of global reach in which heterogeneous products were exchanged among groups from different backgrounds. However, this combination of characteristics, product heterogeneity, global reach, and participant diversity, that distinguished the trade, also hindered its expansion by creating uncertainty in sourcing, exchanging, and delivering a product. The discovery of many new zoological specimens threatened to overwhelm emergent and often competing taxonomies and classification systems that had been proposed in the eighteenth century. ${ }^{37}$ Lack of an agreed specific identification of a specimen, and its relationship to others, made it difficult for distant buyers to be certain what they were purchasing and to know a fair price to pay. Indeed, the same problem might be faced by sellers, cautious about giving away cheaply a 'bling'

\footnotetext{
${ }^{37}$ Hugh Strickland, 'Report of a Committee appointed to consider of the Rules by which the nomenclature of zoology may be established on a uniform and permanent basis'. Report of the Meeting of the British Association for the Advancement of Science, 12 Manchester 1842, pp. 105-120; L.C. Rookmaaker, 'The early endeavours by Hugh Edwin Strickland to establish a code for zoological nomenclature in 18421843 ', The Bulletin of Zoological Nomenclature, 68, 1, 2011, pp. 29-40.
} 
item of great rarity. Nor were relative prices stable, because the demand and supply of particular species fluctuated over time and between regions. Heterogeneity existed, even among specimens of the same animal species, for various reasons including the health of the animal, the manner in which it was killed, and the relative ineffectiveness of subsequent handling and preservation processes.

Just as long distances hindered the acquisition of timely and rich information on which to judge price and quality, the handling and transport of unstable zoological products demanded care and expertise. In contrast to commodity trades, such as coal or wool, specimens were often sourced from remote and dispersed locations. In the eighteenth century, the communications, logistics, and financial systems that supported commerce had been poorly equipped to deal with these challenges. Thus, a Quebec-based naturalist Jean-François Gaultier wrote in 1754, 'a stuffed seal skin has already arrived with its head [intact]. But the entire thing was in such bad condition that I could not imagine that I could send it to you.'38 Whole collections of animal specimens shipped to Europe were frequently burned or destroyed because of their deteriorated condition, among them the French Royal and Sir Hans Sloane collections. Communication systems travelled at the speed of sailing ships. ${ }^{39}$ Cargo handling, on-board stowage, and warehouse storage relied on centuries old methods of manual transfer designed for relatively homogenous, stable and sturdy bulk cargoes such as timber, coal, wool and cotton rather than fragile, heterogeneous products. When Robert W. Stevens published his important work, On the Stowage of Ships and their Cargoes in 1858, he noted in the

\footnotetext{
${ }^{38}$ Christopher M. Parsons and Kathleen S. Murphy, 'Ecosystems under sail: specimen transport in the eighteenth-century French and British Atlantics', Early American Studies, 10, 3, 2012, p. 527.

${ }^{39}$ Steven. C. Topik and Allen Wells, Global markets transformed, 1870-1945, Cambridge, MA: Harvard

University Press, 2012, p. 49.
} 
preface, 'this is the first attempt to compile, in a systematic form, instructions on the subject of stowage'. ${ }^{40}$

A further issue concerned the financial systems that supported international commerce, which were a mix of trade credit provided by transactors, along with short and long term funds from intermediaries, who were either commercial bankers or sector specialists. None of these options were straightforward for the zoology trade. Banks relied on accurate trade valuations; specialist financial intermediaries were a function of larger, more regular trades such as wool and coal. Trade finance along the supply chain was difficult because of the participation of many different groups whose members were rarely known to each other.

The following section investigates the ways in which the complementary capabilities and interactions among business, science and leisure served to mitigate many of these constraints on the development of a market in zoological collecting. Some of the more important aspects may be foreshadowed here. During the nineteenth century more accurate relative price information was facilitated by the development of scientific classification, by the holding of exchange lists by museums, and through the wealth of exhibitions, displays, journals and marketing information that revealed key sources of product knowledge and consumer preferences. A variety of alternatives to the price mechanism aided the development of a market, often through informal negotiated exchanges such as barter, swaps, and exhibits. The much improved practice of taxidermy boosted consumption by extending product life. It also fed back into hunting practices and stabilised products in long distance transit by emphasising the importance of cleaning and preparing skins adequately. New transport and

${ }^{40}$ Robert White Stevens, On the stowage of ships and their cargoes, London: Longmans, 1858. 
communications technologies, improved international payments systems and larger companies with international reach assisted the handling, financing and organisation of this long distance trade.

Underlying these solutions, were the factors which helped to foster trust and cooperation across the different groups. Building cooperative networks was facilitated by the growing importance of major firms and museums that provided networking space in trading rooms and at exhibitions. The fluidity of roles of several key figures connected different groups and overcame distance. The 'branding' of reputations of learned scientists, wealthy dealers, and socially esteemed gentlemen collectors reached out to a much wider public interest in zoology collections.

\section{Trust-building networks}

The foundation for addressing all of the sources of uncertainty in the natural history trade - product heterogeneity, global reach, participant diversity - was the development of trust among the different parties. Heightened trust reduces the 'transaction costs' of trading, that is, the time and effort spent negotiating, monitoring and completing an exchange. ${ }^{41}$ Where a trade contract is complex - for the sort of reasons mentioned above - parties will need to expend more time ensuring the terms are fulfilled and in the end may decide the effort is not worth it. The exchange fails to take place due to high transaction costs. Where trust between the parties is high, they will more readily cooperate and spend less time verifying the transaction. Social scientists have extensively analysed how trust is built in trading relationships through

${ }^{41}$ Douglass C. North, Institutions, institutional change and economic performance, Cambridge: Cambridge University Press, 1990, pp. 27-35. 
the development of forms of social capital. ${ }^{42}$ Social capital often flourishes where individuals share similar values that are regularly reinforced by interaction as part of an association or community.

The existence of meeting places provided opportunities for face to face interaction in the specimen trade. Despite the geographic distances involved and the participation of disparate social and economic groups, there were many points of contact and network building. The retail shops of dealers, the field laboratories and galleries of museums and research centres, the meeting rooms of societies, the halls of international exhibitions, the inspection rooms of auction houses, and the shared experiences of expeditions all served as networking spaces. In London's fashionable Piccadilly district, Rowland Ward's shop, also known as 'The Jungle', gave sports shooters, museum curators, and collectors a place to congregate and see his most recent displays. ${ }^{43}$ At the New York premises of taxidermist John G. Bell, 'a wide array of sportsmen, collectors, and naturalists gathered regularly to exchange stories, to pour over the latest acquisitions, and to purchase specimens.' ${ }^{44}$ Bell was taxidermist to John Audubon, and also gave lessons in taxidermy to Theodore Roosevelt. William John Macleay funded and organised day trips in New South Wales, Australia, for Linnean Society members and his circle of collectors. Spending the day together while collecting, discussing and examining species, was similar to the interaction that occurred in the Society's rooms, but with the advantage of potential discovery. A field station operating at Ralum, New

\footnotetext{
42 Robert I. Rotberg, ed., Patterns of social capital: stability and change in historical perspective, Cambridge: Cambridge University Press, 2001; Gordon Walker, Bruce Kogut and Weijian Shan, 'Social capital, structural holes and the formation of an industry network', Organization Science, 8, 2, 1997, pp. 109-125; David Merrett, Stephen Morgan and Simon Ville, 'Industry associations as facilitators of social capital: The establishment and early operations of the Melbourne Woolbrokers Association', Business History, 50, 6, 2008, pp. 781-94.

${ }^{43}$ Rowland Ward, Records of big game with their distribution, characteristics, dimensions, weights, and measurements of horns, antlers, tusks, \& skins, London: Ward, 1899. For Ward's animal furniture and trophy taxidermy see Pat Morris, Rowland Ward: taxidermist to the world, London: MPM Publishing, 2003. ${ }^{44}$ Barrow, 'The specimen dealer', p. 499.
} 
Britain in the 1890s illustrated the typical network needed for the international trade in natural history. Its staff included an academic scientist, a professional museum worker, a self-taught established field collector, and two men recruited from the local population who were trained in Naples for the work. ${ }^{45}$

It has been found, however, that the social capital generated by regular personal interaction often wanes when distance and time intervene. In this case the popularisation of collecting in the nineteenth century at times overwhelmed the deep personal connections through which social capital often flourishes. Cultivating a positive reputation could be an effective way of communicating trustworthiness both among elites and, as a form of branding, to a wider audience of collectors. Leading traders, therefore, signalled their reliability through activities that reaffirmed their professional standing. Invaluable publicity was gained from impressive displays in the halls of national and international exhibitions that showcased the resources, industries, arts and crafts of many nations. In the United States and Europe, companies like Maison Verreaux and Ward's Natural History Establishment staged extensive displays. At the Chicago Columbian Exhibition in 1893, Ward's display, subsequently purchased to found the Chicago Field Museum, took up an area of more than 11,000 square feet. ${ }^{46}$ Exhibitions provided the opportunity for further reputation-building through the written word. At the same exhibition, 10,000 visitors, impressed by the display of the American natural history dealer Frank H Lattin, signed up to receive his catalogue. ${ }^{47}$ Lattin was the editor and publisher of National Science News, a weekly journal containing information, advertisements, and listings of duplicate natural history

\footnotetext{
45 Elisa Marie Schmitt and Matthias Glaubrecht, "Give me a museum and I will fill it". The first German Tropical Research Station at Ralum, Bismarck Archipelago, 1896-1897, in context of collecting for the Museum of Natural History Berlin', Zoosystematics and Evolution, 89, 2, 2013, pp. 337 - 364.

46 Barrow, 'The specimen dealer', p. 507.

47 Barrow, 'The specimen dealer', pp. 521-522.
} 
material offered for exchange. In January 1896 he advertised for sale a black dolphin, a white shark and a hammerhead shark, acquired through a 'swap' and 'all nicely mounted and in A no. 1 condition'. ${ }^{48}$ While ostensibly designed as a marketing and sales tool, such information in print heightened the company's standing in the trade.

Newspaper publicity raised profiles too. Articles published about, or by, collectors in the field provided evidence of their skill, knowledge and reliability, as did news items highlighting the achievements of particular retailers. ${ }^{49} \mathrm{~A}$ local firm, Tost and Rohu, had their contribution to the Sydney Exhibition of 1879 described in detail by the Sydney Mail, a newspaper read across New South Wales, which also noted the proprietors' success in winning medals at 'two Sydney exhibitions and one at the London exhibition of $1862^{\prime} .{ }^{50}$ Another frequent medallist, Rowland Ward, published in areas that capitalised on the cross-over between sports and science. Such reputation development by leading traders impressed museums as well as individual collectors. Sir Frederick McCoy, a Professor and Director of the Victorian Museum (1857-99) in Melbourne, exemplified the new era of professional collecting by museums. He relied heavily upon commercial exchanges with professional dealers and was disdainful of 'ignorant amateurs'.51

The development of trust among disparate groups worked best when it involved individuals who were well placed to forge connections and develop bridging forms of social capital. The term 'boundary spanners' is commonly used to describe those

\footnotetext{
48 Frank H. Lattin, 'Whales and sharks', Natural Science News, 1, 50, 1896, p. 196.

${ }^{49}$ See for example, Sydney Morning Herald, 20 April 1844, 2; 17 July 1848, p. 3; 2 January 1850, p. 1; 26 January 1850, p. 4; 6 December 1852, pp. 2, 3.

50 Sydney Mail and New South Wales Advertiser, 4 October, 1879, p. 564.

${ }^{51}$ Gareth Knapman, 'Curiosities or science in the National Museum of Victoria: Procurement networks and the purpose of a museum' in Sarah Longair and John McAleer, eds., Curating empire: Museums and the British imperial experience, Manchester: Manchester University Press, 2012, p. 89.
} 
individuals able to link information and knowledge between different 'systems'. ${ }^{2}$ Some important figures in the nineteenth-century trade had not pursued specialised occupations; instead, they demonstrated flexibility in their roles as sometime collector, trader, or researcher. Their ability to traverse different groups proved valuable in fostering communication and trust. Many were wealthy individuals whose involvement in the trade was not generated by the need to pursue monetary profit or embark on scientific achievement.

One such individual was Walter Rothschild of the famous European merchant banking family who, besides extraordinary wealth, had ability and purpose. After several years working in banking, he convinced his father that he was no use to the family business and was given a staggering $£ 1$ million to establish himself in the field of zoology. His was a scientific endeavour embedded in taxonomy but combined with the aim of public education and public good. He developed a network of an estimated 400 collectors, and, drawing on business connections, also employed intermediaries such as South Seas traders Burns-Philp \& Co in British New Guinea to set up and coordinate local collecting. Dealers like Boucard sought to satisfy his desire for particular birds acquired with scientific aims in mind, rather than for beauty or millinery. ${ }^{53}$

Dealings between the British ornithologist and publisher, John Gould, and the commercial collector, Frederick Strange, illustrate how a key figure could also function as a 'boundary spanner' by fostering trust among the social diversity of stakeholders. Strange, a poorly educated former seaman who collected in Australia and New Zealand

\footnotetext{
52 Michael L. Tushman, 'Special boundary roles in the innovation process', Administrative Science Quarterly, 22, 4, 1977, pp. 587-605; James S. Coleman, 'Social capital in the creation of human capital', American Journal of Sociology, 94, S1, 1988, pp. S95-S120; Ronald S. Burt, 'Structural holes versus network closure as social capital', in Nan Lin, Karen S. Cook, and Ronald S. Burt, eds., Social capital: theory and research, New York: Aldine de Gruyter, 2001, pp. 31-56.

${ }^{53}$ Miriam Rothschild, Dear Lord Rothschild: birds, butterflies and history, London: Hutchinson, 1983.
} 
during the 1840s and early 1850s, supplied some of the birds and quadrupeds required for Gould's publications, and also sent other items that Gould endeavoured to sell on his behalf. As a member of London's Zoological Society, as well as a man of business, Gould had an extensive scientific and commercial network. Thanks directly and indirectly to his relationship with Gould, Strange received orders from the Earl of Derby, supplied molluscs to Professor Richard Owen, and sold at least one small collection of specimens to the British Museum. He was also able to trade with such notable metropolitan natural history dealers as Hugh Cuming and George Sowerby in London, and Edouard Verreaux in Paris. ${ }^{54}$

\section{Prices and markets}

By the beginning of the nineteenth century, the burgeoning range of natural history products and competing classification systems confounded the process of agreeing an exchange price. However, this was beginning to change as advances in scientific knowledge and practice lubricated the expansion of trade. Important developments in specimen classification and preservation eased the process of agreeing a price by creating a more homogenous and well-defined product. The system Linné developed in the eighteenth century was binomial - the first word refers to the genus, the second to the species so that the combination of genus and species is unique to that species.

\footnotetext{
${ }^{54}$ Anne Coote, "Pray write me a list of Species ... that will pay me best": The business and culture of natural history collecting in mid-nineteenth century New South Wales', History Australia, 2, 2, pp. 85-86; Gordon C. Sauer, and Anne Datta, John Gould The Bird Man: correspondence: with a chronology of his life and works, Mansfield Centre, CT, Maurizio Martino Publisher, 1998; Frederick Strange to John Gould, 24 July 1847, Vol. 4. p. 161; Strange to Gould, 4 August, 1847, ibid., p. 164; 1 October 1847, ibid., p. 172; 6 October 1847, ibid., p. 173; 9 November 1847, ibid., p. 182; 14 November 1847, ibid., p. 185, 14 August 1849, ibid., p. 328; Strange to Lord Derby, 14 July 1849, ibid., p. 320; Gould to Sir William Jardine, 1 July 1852, ibid., Sauer and Datta, John Gould, Vol. 5, p. 50; Gould to Edouard Verreaux, 22 July 1852, ibid., pp. 53-54.
} 
Daniel Solander and Johan Fabricius, along with other students of Linné, worked to refine the system after his death. Solander catalogued the collections of public institutions such as that of the British Museum, as well as those of private collectors like the Duchess of Portland and the public-private collection of Joseph Banks. There were mutual benefits to be had. Solander had unprecedented access to the great variety of novel species pouring into Europe, while his clients learned more about the Linnean system of classification, enabling them to conduct exchange and increase the value of their personal collections.

As Solander and others worked to improve taxonomic knowledge, different interpretations of the Linnean system, along with slow communication across the continent, led to a variety of names being applied to a single species, ironically the very outcome Linné had attempted to prevent. A breakthrough came, but not until the 1830 s and 1840s, with the recognition of the a priori status of specimens used for the first published description. This breakthrough was significant for the collecting trade. A given collection could be valued from its type specimens: the zoological object that had to be studied to understand the place of the specimen in relation to all others of its genus or family. The prestige of authoring a definitive account of a new species or family also gave impetus to collectors acquiring as many specimens as possible for comparative purposes.

Improvements in taxidermy practices went hand in hand with those of taxonomy in fostering a wide market. The science of classification required great numbers of suitably prepared specimens that accurately represented the animal for comparative study. From the beginning of the nineteenth century, collecting guides for natural history included taxidermy instructions with storage advice. At the point of field collection little 
had changed in preparation methods from the eighteenth century, although specific collectors marketed their abilities by asserting that their recipes were the most effective. Field preparations were aimed at ensuring the specimen was kept in the best possible condition until it became part of a domestic or museum collection. Some animals, post mortum, were simply plunged in alcohol for transport. This method occasionally resulted in ruffled plumage or fur, or discolouration. It also meant that field collectors had to carry with them hefty metal containers, or well fitted wooden containers with compartments for glass bottles, and had to negotiate for access to raw alcohol in sufficient quantities.

Alternatively the animal could be immediately dissected to remove all wet matter (flesh, muscle, organs). During the nineteenth century, with subtle differences over time and between zoological orders, the principal active ingredients of alum (as a drying agent) and arsenic in the form of soap (as a pesticide) were applied to specimen skins before packing out the interior with cotton or flax. Although the techniques were known early in the century, ill-prepared collectors did not always have access to the necessary supplies of arsenic, alum, cotton and boxes. A badly prepared skin could be more vulnerable to pests and mould or, in the case of birds, the whole body could be affected by 'feather strike', which damages the appearance of each feather. To counter this in tropical conditions, a bird collector needed to work quickly, often at the hottest point of the day, when the birds were dormant. However, removing a bird's head to extract the brain and other wet material in the most expedient method might also affect the stability of the bird for subsequent taxidermy, as when the head was replaced it was only supported and connected to the body by a single wire. 
Improvements in field preparation laid the basis for developments in taxidermy. Broadly speaking, the first half of the century was an era when animals were taxidermied to show their taxonomic features, and arrangements of similar animals emphasised the comparative zoological purpose. By the century's end, two different kinds of preparations were employed, each depending on the final use of the specimen. Skins were softly stuffed or whole specimens placed in spirit, but both forms were minimally manipulated for study and exchange purposes. For exhibition, skins were manipulated and mounted in positions. ${ }^{55}$

As part of an iterative process, the trade in turn contributed variously to advancing the scientific knowledge of species. Commercial collectors and dealers sourced, transported, exhibited and sold a large proportion of the animal species that found their way into the collections of leading naturalists and museums. For enthusiasts and expert naturalists unable to secure a salaried scientific post, the natural history trade offered opportunities to contribute to scientific knowledge, while making a congenial living. The London dealer, Samuel Stevens, a member of an auctioneering family and an expert entomologist in his own right, acted as agent for Alfred Russell Wallace, who collected in South America and in the Malay Archipelago. Wallace, well known for his contribution to the theory of evolution, relied on Stevens to process and preserve the specimens he sent home as part of his private collection. By arranging the sale of numerous other specimens from Wallace, Stevens financed the naturalist's collecting expeditions. He also supplied Wallace with provisions and passed on to him the latest scientific information. According to Wallace's biographer, this relationship with Stevens was 'a

\footnotetext{
55 Jude Philp, 'The natural object', Journal of Museum Ethnography, 29, 1, 2016, pp. 11-28.
} 
major component of Wallace's development as a scientist'. ${ }^{56}$ Other scientists gained valuable experience in their youth by working for dealers and mixing with the naturalists who visited them. Barrow notes that the 'graduates' of Ward's establishment included three college professors, three museum directors, and a director of New York's aquarium. ${ }^{57}$ The scientific and research community, in turn, rewarded the trade by disseminating information about new species classifications through individual publications and the journals and public lectures of their professional organisations and societies.

While the development of scientific knowledge of the species aided price determination, and improved preservation techniques reduced heterogeneity, the trust generated by personal connections was not easy to establish. There was still considerable uncertainty about buying and selling to unknown parties in distant locations without viewing the specimen beforehand. Alternative forms of exchange coordination were developed that overcame some of these remaining obstacles. Open cry auctions, when buyers shouted out their bids, were common in commodity trades, most famously in much of the wool trade by the nineteenth century, but also for more specialist commodities such as indigo. ${ }^{58}$ They provided the opportunity to inspect the sale product beforehand and, as a centralised market, the ability to compare many offered items of varying quality. Observing the sales themselves revealed further relative price and quality information for heterogeneous products. It also brought together many buyers and sellers in a single saleroom and facilitated network-style interaction along the lines mentioned earlier. In

\footnotetext{
${ }^{56}$ Martin Fichman, An elusive Victorian: the evolution of Alfred Russel Wallace, Chicago, IL: University of Chicago Press, 2004, p. 22.

${ }^{57}$ Barrow, 'The specimen dealer', pp. 499, 501, 508, 510.

${ }^{58}$ Simon Ville and David Merrett, 'Accounting for non-convergence in global wool marketing before 1939: the iron cage unlocked', Business History Review, 89, 2 2015, pp. 229-53; Michael Aldous, 'Rehabilitating the intermediary: brokers and auctioneers in the nineteenth-century Anglo-Indian trade', http://dx.doi.org/10.1080/00076791.2016.1220939
} 
the wool trade, the specialist brokers became highly knowledgeable, able to assist with storage, presentation, and the combined sale of similar small lots. Contemporaries were in little doubt about the benefits the system could offer, especially for very diverse products. ${ }^{59}$

While not on the same scale as wool, thousands of natural history specimens changed hands at auction. ${ }^{60}$ A register of natural history auction sales in Britain compiled by J. M. Chalmers-Hunt (acknowledged by the complier as by no means complete) records nearly two and a half thousand separate lots of natural history specimens put up for auction between 1840 and $1910 .{ }^{61}$ Items came from afar - Lapland, Norway, Sweden, Mauritius, Turkey, South America, Australia, Canada, Trinidad, South Africa, India - a further reminder of the geographic reach of the natural history trade. The register records the names of 45 auctioneering firms that handled specimens in England and Scotland. They operated in English and Scottish provincial cities like Birmingham, Manchester, Leeds, Edinburgh and Glasgow but also in such smaller centres as Ramsgate, Greater Yarmouth and the Isle of Wight. However, most took place in London, the great majority of these going under the hammer at a Covent Garden auction house specialising in natural history and owned by John Crace Stevens and his family and descendants from 1834 until the 1940s. ${ }^{62}$

\footnotetext{
${ }^{99}$ A. F. Du Plessis, The marketing of wool, London: Pitman, 1931, p. 135; Gerda Blau, 'Wool in the world economy', Journal of the Royal Statistical Society, 109, 3, 1946, p. 216.

${ }^{60}$ Samuel J. M. M. Alberti, 'Objects and the museum', Isis, 96, 4, 2005, p. 564; Robin Torrence and Annie Clarke, "Suitable for decoration of halls and billiard rooms": Finding indigenous agency in historic auction and sale catalogues', in Sarah Bryne, Anne Clarke, Rodney Harrison, and Robin Torrence, eds., Unpacking the collection: networks of material and social agency in the museum, New York: Springer, 2011, pp. 29-53. ${ }^{61} \mathrm{~J}$. M. Chalmers-Hunt, Natural history auctions 1700-1972: A register of sales in the British Isles, London: Southerby Parke Bennet, 1976.

${ }^{62}$ Horniman Museum and Gardens, 'J C Stevens', http://www.horniman.ac.uk/collections/browse-our-collections/authority/agent/identifier/agent3764/page/2 (consulted 20 October 2015).
} 
Much of what was sold by auction had been the property of cabinet collectors, erstwhile dealers, or learned societies, and may have been traded through several hands before coming up for auction. But some lots came directly from field collectors in distant places. A British officer sold animals amassed while on active service in India, former members of scientific expeditions sold their personal collections, and in 1888 Alfred Russel Wallace and Henry Walter Bates sold butterflies they had gathered during their scientific investigations along the Amazon. ${ }^{63}$ Most items put up for auction in Britain had apparent scientific value, attracting as bidders not only commercial dealers, but buyers from private and public museums, as well as independent expert naturalists. Curators were frequently invited to pre-sale viewings, ostensibly allowing them time to raise the necessary finances for purchasing at auction (and sometimes beforehand).

Cash and credit were central to transactions in the zoology trade, but barter was important as well. In nineteenth-century Europe the exchange of information and objects of scientific interest between learned organisations was already a wellestablished custom; the many private and public museums founded in this period took up the practice to help swell their collections by trading unwanted or duplicate items. ${ }^{64}$ A number of organisations, such as the Smithsonian Institution in Washington DC and the Natural History Museum in Leiden, produced catalogues of exchange lists providing bilateral values, to facilitate such transactions. In the late nineteenth century an extensive set of exchanges occurred between Auckland Museum and Florence's Natural History Museum across at least 25 years. In a series of regular consignments some 150 New Zealand birds were conveyed to Florence, and more than 600 Italian and foreign

\footnotetext{
63 Chalmers-Hunt, Natural history auctions, pp. 103, 107, 121, 141.

${ }^{64}$ Sarah S. Gibson, 'Scientific societies and exchange: A facet of the history of scientific communication', Journal of Library History, 17, 2, 1982, p. 144; Samuel J. M. M. Alberti, 'Placing nature: Natural history collections and their owners in nineteenth-century provincial England', The British Journal for the History of Science, 35, 3, 2002, pp. 291, 304.
} 
birds, mammals, reptiles and amphibians went to Auckland. ${ }^{65}$ Multilateral exchanges were also common with reciprocal relationships among collecting institutions and learned societies in Britain, Cape Colony, New South Wales, and India. ${ }^{66}$

Specimens were also bartered for unrelated 'trade goods' and non-material rewards including labour. In one case, a lithographic press and some associated equipment were exchanged for bird skins. ${ }^{67}$ Using natural history specimens, vendors could also purchase patronage. In her study of the networks of influence crisscrossing the British Empire in the first half of the nineteenth century, Zoe Laidlaw argues that one way in which colonial officials sought professional advancement was by establishing contacts among influential individuals in the metropole, known to have an interest in natural history. Across the empire, local artefacts and specimens from the colonies flowed in one direction, 'while [p]atronage, goodwill and money flowed back through the network in response'. ${ }^{68}$

\section{Supply chain logistics}

Alongside advances in scientific knowledge (classification), practice (preserving), and organisational developments in exchange methods, came the technological revolution in transport and communications that further stimulated the growing trade in zoological items. In particular, the switch from wood and sail to steel and steam in shipping, the

\footnotetext{
65 Brian J. Gill, 'The Cheeseman-Giglioli correspondence, and museum exchanges between Auckland and Florence, 1877 - 1904', Archives of Natural History, 37, 1, 2010, pp. 131-149.

${ }^{66}$ R. Etheridge, 'The Australian Museum-fragments of its early history', Records of the Australian Museum, 12, 12, 1919, pp. $356-57$.

67 Hugh Strickland to Gould, 11 November 1847, Sauer, and Datta, eds., John Gould, pp. 183-184.

68 Zoe Laidlaw, Colonial connections 1815-45: Patronage, the information revolution and colonial government, Manchester: Manchester University Press, 2005, pp. 33-34.
} 
introduction of railways, and the building of international telegraphic cable networks are well known developments that, John MacKenzie notes, 'were vital in the physical accumulation of collections, as well as in the exchange of ideas and people'.69 Shorter and less variable travelling times reinforced the benefits of improved field-based preservation to assist the growth of long distance trade in zoological specimens. ${ }^{70}$ Instant communication facilitated the growth of timely information about sale products.

There was a business as well as an economic component to the development of global trade in the nineteenth century with the growth of large scale and international business. British trading companies and banks played a vital coordinating role in the growth of long distance commodity trades by providing a network of company offices in many countries, or at least a network of trusted agents and brokers, to handle precious items. ${ }^{71}$ International banking assisted payment between parties unknown to each other as was often the case in the natural history trade. The growth of international monetary and exchange rate systems and payment mechanisms reinforced the work of these companies. ${ }^{72}$

Important though these major infrastructural changes must have been to all trades, currently we lack detailed analyses of their impact on natural history trading. Greater speed of transport and information flows, along with careful product handling, obviously mattered, especially in the secondary market and final stages of the supply chain in Europe, North America and some key Asian ports. From the mid nineteenth

\footnotetext{
${ }^{69}$ MacKenzie, Museums and Empire, p. 9.

${ }^{70}$ Simon Ville, Transport and the Development of the European Economy, 1750-1914, Basingstoke, Macmillan, 1990, pp. 108-12, 154-71 provides evidence of shorter journey times by rail and sea. ${ }^{71}$ Geoffrey Jones, British multinational banking, Oxford: Clarendon Press, 1993; Geoffrey Jones, Merchants to multinationals: British trading companies in the nineteenth and twentieth centuries, New York: Oxford University Press, 2000.

72 Barry Eichengreen, Globalizing capital: a history of the international monetary system, Princeton, NJ, Princeton University Press, 2008.
} 
century, these seaborne routes were increasingly served by the liner trades which operated regular services between specified destinations. With the benefits of publications on stowage advice, these vessels were able to safely carry a variety of different cargoes at the same time. Robert Stevens' book, mentioned earlier, discusses in detail the stowage and safe carriage of many goods, including natural history products.

Natural history dealers also turned to specialist intermediaries from major commodity trades when shipping specimens by freight. Shipping and consigning agents arranged for their conveyance by sea along established trade routes. The detailed export lists published in nineteenth-century newspapers reveal that the shipment of zoological items was often managed by the same merchant firms that handled other commodity exports. The burgeoning wool export trade, for example, fostered specialist consigning agents who were prepared to arrange shipment of some specimens alongside their main wool cargo.

However, the geographic dispersion of animal specimens created greater challenges at the procurement stage than did commodities such as wool or wheat, which were more footloose and whose production locations were designed, where possible, to integrate with the emerging transport infrastructure. The more remote and irregular routes, often used in collecting, did not justify the required extensive capital investments so the transport transitions, international payments mechanisms, and company networks came later. In such cases, the trade had to adapt in order to evolve.

Some of the larger natural history traders could draw on their own resources or wellestablished commercial contacts. Sales negotiations were conducted by mail where national and international telegraphic communication was unavailable. The same can be 
said for the management of payments. Most financial documents, such as invoices, letters of credit to banks in distant places, power of attorney documents, and the paperwork for sums drawn in advance, travelled by mail. Postal services also carried newspapers and magazines as providers of broad and specific commercial information, whose titles multiplied and whose circulations expanded in European countries and their colonies. Specimens also travelled this way. '[S]end them to me by ... the Messageries of France which is the most expeditious although a bit costly', wrote Joseph Gené to John Gould in 1842, in regard to the bird skins Gould had promised him. ${ }^{73}$ To avoid the expense of sending goods by mail, dealers also entrusted specimens to friends and connections who happened to be traveling in the desired direction. ${ }^{74}$ These included naval officers, ships' captains, supercargoes, even merchant seamen, and missionaries. Czech natural history dealer Vaclav Fric was able to source specimens from Africa, Asia and South America through a range of contacts including traveller Enrico Stanko Vráz, whose finds included a Japanese giant crab and an African lungfish, both highly prized. ${ }^{75}$ By the final quarter of the nineteenth century, though, the network of parcel post had grown rapidly and the cost had fallen, assisting consignment to many parts of the world. 76

Sourcing original specimens from often remote and dispersed locations was perhaps the biggest logistical challenge, especially in areas not served by railways or regular

\footnotetext{
73 Joseph Gené to Gould, 20 May 1842, Sauer, and Datta, eds., John Gould, 3, p. 55.

74 William Thomson Bednell to John Braizier, 31 March, 1890, John Brazier, letters and papers, State Library of New South Wales, ML A146511; Bednell to Braizier, February 1892, ibid.; E. Verreaux to Gould, 28 September 1845, Sauer, and Datta, eds., John Gould, 3, p. 437; Strange to Gould, 27 December, 1845, ibid., p. 455.

${ }^{75}$ Henri Reiling and Tat'jána Spunarová, 'Vaclav Fric (1839-1916) and his influence on collecting natural history', Journal of the History of Collections, 17, 1, 2005, pp. 23-43.

76 Léonard Laborie, 'Global commerce in small boxes: parcel post, 1878-1913', Journal of Global History, 10, 2, 2015, pp 235-258.
} 
steamship services. ${ }^{77}$ The ocean cable, providing more instantaneous contact, had achieved significant coverage by the 1870 s but remained expensive and restricted to specific locations. ${ }^{78}$ Facing such challenges were a diverse set of actors, ranging from part-time hunters, missionaries, and members of the army and navy to individual salaried and commercial collectors. ${ }^{79}$ As the nineteenth century progressed, however, some substantial specimen-collecting expeditions were organised, often in remote areas, with major financial backers. While expeditions were not new, the growth of scientific and commercial interests in new species heightened interest and generated substantial enterprises. Examples included the global navigation of the Challenger expedition (1872-76), funded by the Royal Society and the Admiralty; the Horn Expedition to Central Australia (1894), supported by three universities; and the Hall and Trebilcock voyages to Siberia and the Arctic Tundra (1903) that relied on the sale of captured birds. ${ }^{80}$

Both individual field collectors and expeditions possessed of extensive financial, logistical and scientific resources often drew upon extensive networks of people from the point of source, who in many cases provided their indigenous knowledge of the area and its peoples. Sometimes hired for the journey, or engaged by collectors on the spot, indigenous people served as guides in unknown terrain, as diplomats, interpreters, carriers and suppliers of food. ${ }^{81}$ They also contributed to the acquisition of specimens by sharing their environmental knowledge and hunting skills. In the Seychelles, Robert

\footnotetext{
77 Topik and Wells, Global markets transformed, p. 49.

78 JoAnne Yates, 'The telegraph's effects on nineteenth-century markets and firms', Business and Economic History, 15, 1, 1986, p. 152.

${ }^{79}$ Bettins Dietz, 'Making natural history: doing the Enlightenment', Central European History, 43, 1, 2010, p. 29; Jivanayakam C. Daniel and Baljit Singh, Natural history and the Indian army, Bombay: Oxford University Press, 2009.

${ }^{80}$ Libby Robin and Anna Sirina, 'Siberian ornithology - Australian style, 1903', 2003, http://fennerschoolassociated.anu.edu.au/siberia/ (consulted 26 March 2016).

81 See, for example, Frank David, Leah Lui-Chivizhe and Jude Philp, 'Individuals in Kulkalgal history', Journal of Australian Studies, 39, 3, 2015, pp. 290-306.
} 
Plant depended on his local helpers, William Wallace made extensive use of indigenous assistance in the area around modern-day Malaysia and Indonesia, while expeditions into remote inland regions of Australia usually drew upon the assistance of Aboriginal people. 82

All of this suggests some degree of continuity with procurement practices prior to the nineteenth century, but the expansion thereafter of commerce and scientific research in natural history increased the importance of local cooperation. Hugh Cuming serves as an example of the extensive knowledge of supply-chain logistics needed by collectors in remote locations. Over a period of three years in the 1830s, this natural history dealer used government and regal intermediaries in the Philippines to access lands; moved laborers from one coastal site to another to collect shells; warehoused collections ready for transit in key ports whilst keeping a sharp eye on passing shipping to gradually move the thousands of animals collected to the United Kingdom. Recognizing the importance for his business in having specimens in the leading taxonomic institutions, he had developed his relationships with Joseph Hooker and Richard Owen and so could request that they send specific specimens on to the Zoological Society and the British Museum on his behalf. ${ }^{83}$

\section{Conclusion}

\footnotetext{
82 Donald McCracken 'Robert Plant (1818-1858): A Victorian plant hunter in Natal, Zululand, Mauritius and the Seychelles', South African Journal of Science, 107, 3-4, 2011, pp. 1-7; Alfred Russel Wallace, The Malay Archipelago: the land of the Orang-utan and the Bird of Paradise. A narrative of travel with sketches of man and nature, Adelaide: University of Adelaide, 2014; David, Lui-Chivizhe, and Philp, 'Individuals in Kulkalgal history', pp. 307-25.

83 Peter Dance, 'Hugh Cuming (1791-1865) prince of collectors', Journal for the Society of Bibliography of Natural History, 9, 4, 1980, pp. 477-501.
} 
This paper has investigated the trade in collecting a broad range of zoology specimens during the nineteenth century, which extended to many parts of the globe. Its scale, though difficult to measure precisely, throws light on a natural resource commerce that has received very little attention from economists and economic historians who have primarily focussed on industrialisation processes and core commodity trades such as coal, wool and timber. That it existed at all is something of a miracle given the major constraints of remote distance, product complexity, and participant diversity that we have discussed.

In particular, major advances in scientific knowledge (taxonomy) and practice (taxidermy), technology (transport and communications) and organisation (exchange and business) brought about the conditions for a successful trade to flourish. Specifically, the concurrent development of systems to name, transport and stabilise zoology species helped establish long distance sale by private contract. Nonetheless, trading often required alternative forms of exchange coordination to overcome price volatility and complexity. Such exchanges, including barter, swap, exhibition and auction trading, drew on powerful relational elements among groups who were otherwise largely unknown to each other and often separated by long distances. Meeting places helped to develop stocks of social capital and trust, although distance often intervened to deplete these stocks. The local, social and clan networks that often served earlier eras no longer worked in this first epoch of globalisation; instead, trust was generated by establishing a reputation that could register with a much larger and diverse population of collectors.

For all of this to work, however, necessitated not only trust but also a mutuality of needs. This seems to have been the case; since scientists needed the organisation and 
evidence provided by the trade to pursue their work in a rapidly evolving zoological environment. Traders sought scientific knowledge to transact their business effectively and profitably. Collectors relied on scientists to extend their understanding and on business to build their collections. In turn, many collectors connected business with science.

We can take this one step further. It was not only a matter of trust and mutuality that lay at the root of this trade, but, ultimately, a shared view of the world. A long tradition exists in economic history that attributes modern economic development to the foundations laid by the scientific revolution with its emphasis upon understanding facts about the physical world. From the latter evolved 'useful knowledge', which was applied to all manner of problem-solving technology, such as steam propulsion and innovations in industrial dyes. ${ }^{84}$ This Eurocentric view of the world (all the key advances came from a more 'mature' Europe) has been challenged by those who question longer term antecedents of different levels of economic development over several centuries. ${ }^{85}$ More recent work on the relationship between scientific research and business, however, suggests rather than connection through cause and effect, the two spheres, science and business, went hand in hand. The scientific need to understand 'matters of fact' were equally sought after by entrepreneurs developing the commercial systems necessary for success in business, including those governing accounting, financial, organisational, and labour processes. In this light, our study of the zoology trade gives substance to a recent conclusion that 'the modern economy and modern science...were co-produced and

\footnotetext{
${ }^{84}$ Some important contributions include Joel Mokyr, The gifts of Athena: historical origins of the knowledge economy, Princeton, NJ: Princeton University Press, 2002; David S. Landes, The wealth and poverty of nations: why some are so rich and some so poor, New York: W. W. Norton \& Company, 1999.

${ }^{85}$ For example, Kenneth Pomeranz, The great divergence: China, Europe and the making of the modern world economy, Princeton, NJ: Princeton University Press, 2000; Prasannan Parthasarathi, Why Europe grew rich and Asia did not: Global economic divergence, 1600-1850, Cambridge, MA: Cambridge University Press, 2011.
} 
interdependent phenomena'. ${ }^{86}$ We have emphasised some of the vehicles for such cooperation in the nineteenth century including points of common interest, the building of trust through networks and reputation, and the contribution of boundary spanners. During this period successful cooperation between science and commerce in difficult circumstances may therefore be worthy of reflection in the light of modern day dilemmas about bringing the two sectors closer together.

${ }^{86}$ Harold J. Cook, 'Moving about and finding things out: economies and sciences in the period of the Scientific Revolution', Osiris, 27, 1, 2012, p. 102; Kapil Raj, Relocating modern science: circulation and the construction of knowledge in South Asia and Europe, 1650-1900, New York: Springer, 2007, p. 16. 
Figure 1: The Supply Chain of the Natural History Trade

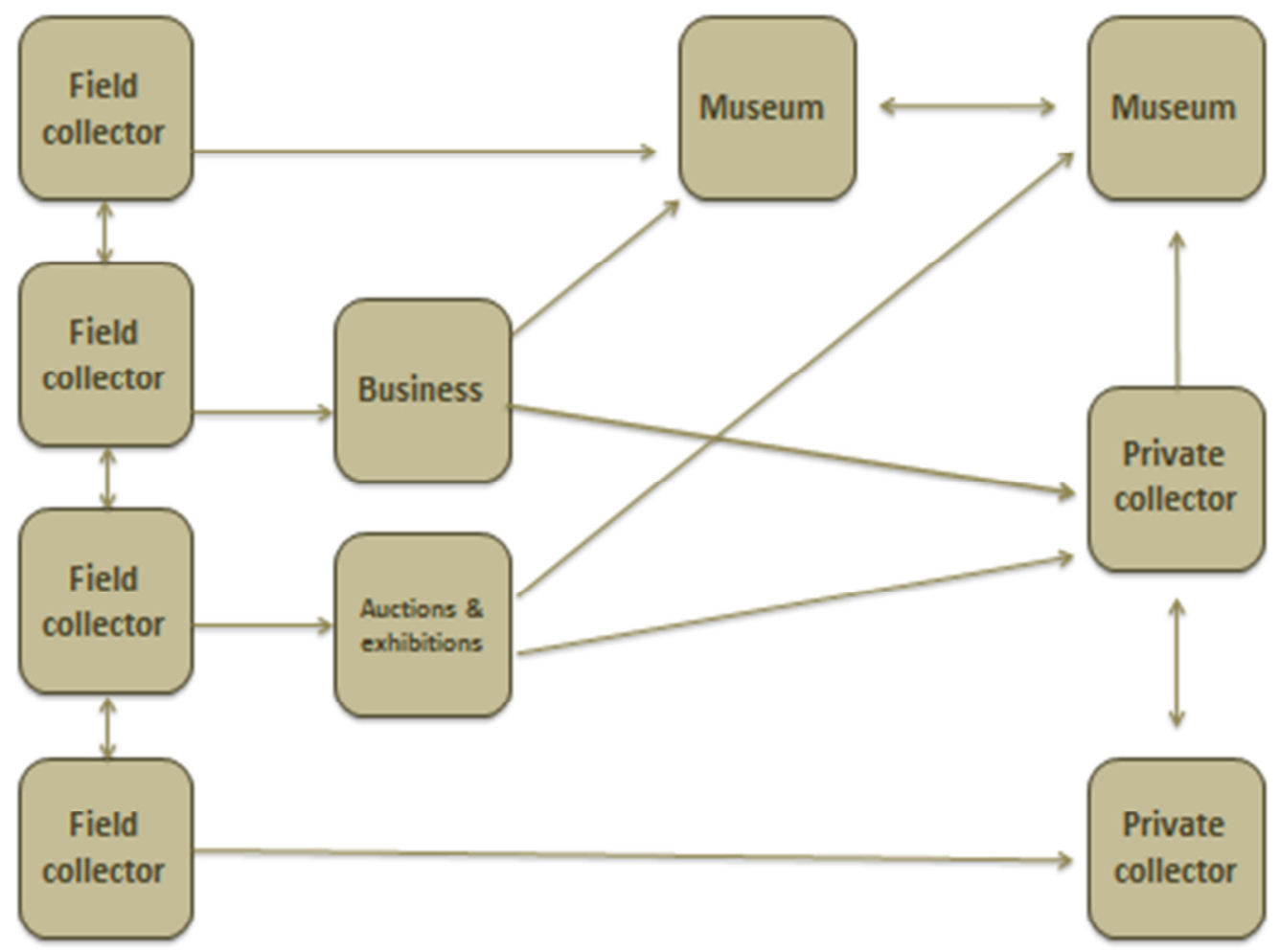




\section{Acknowledgements}

We acknowledge valuable feedback from members of the Colonial and Settlers Studies reading group at Wollongong, particularly Jane Carey, Julia Martinez, Claire Lowrie and Claire Wright. Dierdre Coleman, Jan Brazier, Michael Quinnell and Anthony Gill also offered valuable insights. An earlier version of this paper was presented to the 'Colonial Formations: Connections and Collisions' conference at the University of Wollongong in November 2016. The editors and two referees are also thanked for their very helpful comments. Claire Wright assisted in the preparation of this paper 


\section{Author biographies}

Anne Coote is an Adjunct Associate Lecturer at the University of New England, Armidale, NSW. Her publications on the natural history trade and early science publishing in Australia reflect her broader interests in the cultural history of colonial science.

Alison Haynes is a PhD candidate in biology at the University of Wollongong. She has degrees in English and French law as well as in conservation biology and has worked as an editor and writer in magazine and book publishing.

Jude Philp is Senior Curator of the Macleay Museum, University of Sydney. Her research, publications and exhibitions centre on nineteenth-century natural history and material culture collecting in South-east coastal New Guinea and the Torres Strait and the intersections between European interest and Indigenous purpose.

Simon Ville is Senior Professor of Economic and Business History at the University of Wollongong and a Fellow of the Academy of Social Sciences in Australia. His co-edited Cambridge Economic History of Australia was published in 2015. 